Article

\title{
Smallholder Agricultural Investment and Productivity under Contract Farming and Customary Tenure System: A Malawian Perspective
}

\author{
Emmanuel Olatunbosun Benjamin \\ Department of Agricultural Production and Resource Economics, Technical University of Munich (TUM), \\ 85354 Freising, Germany; emmanuel.benjamin@tum.de; Tel.: +49-8161-71-2772
}

Received: 16 June 2020; Accepted: 17 August 2020; Published: 18 August 2020

\begin{abstract}
Land tenure security, especially customary residence systems, is found to influence the agricultural investment decision-making and productivity of smallholder farmers across sub-Saharan Africa. However, as country-specific customary residence systems and farming models evolve over time, their impact on food security and livelihood remains unclear. This study investigates the impact of customary residence systems on both agricultural investment (in tea shrubs and agroforestry) and productivity among contracted smallholder tea outgrowers in Southern Malawi. A survey of 228 farmers was conducted in 2018, and a linear probability and ordinary least squared (OLS) models were used for the analysis. The results suggest that matrilocal residence practices positively influence agricultural investment. The study concluded that despite the dominance of matrilineal-matrilocal systems in Southern Malawi, there is a need for policy to address gender gaps in the region because women are still vulnerable and insecure even in these assumed women-friendly customary systems. It is recommended that future research explores other prevailing tenure security systems.
\end{abstract}

Keywords: land tenure security; contract farming; tea; agroforestry; investment; productivity; Southern Malawi; sub-Saharan Africa

\section{Introduction}

The 51.3 million smallholder farms (i.e., farms with less than 2 hectares) in sub-Saharan Africa (SSA) are the primary source of livelihood and labor for a large proportion of the population [1]. Thus, land is important for agricultural development in SSA. Any effort to alleviate poverty in sub-Saharan Africa has to pay attention to land and agricultural issues. Land tenure security implies access to use and ownership of land [2]. Land tenure security can be either statutory or customary in nature. Land tenure security enhances the utility that farmers derive from their farmland [3]. For instance, farmers in developing countries that are land secure may enter into new contracts and/or markets [3]. Diverse types of contract farming arrangements have been observed across SSA over the last couple of decades. Therefore, it is plausible to assume that smallholder farmers with adequate land tenure security and access to markets will invest in their land to increase productivity and alleviate poverty. However, studies on the relationship between land tenure security and agricultural investment across sub-Saharan Africa have produced ambiguous results [4]. The differences in these results are often due to limited detailed empirical analysis and vague assumptions on land tenure security $[4,5]$. Given the fact that some of the existing studies do not reflect the reality in the respective countries by neglecting interregional differences and customary tenure arrangements (see [4]), there is a possibility of misplaced and biased policies that may hinder economic development. Therefore, it is important to conduct a country- or region-specific empirical analysis of the relationship between land tenure security and agricultural investment and productivity to have an adequate understanding of reality on 
the ground [4-6]. For instance, Malawi loses approximately 11 million USD per annum in agricultural output due to insecure access, use, and ownership of land [7]. This implies that insecure land rights and tenure can disincentivize farmers from an investment that is vital for agricultural productivity despite contract farming opportunities. Furthermore, the government of Malawi recently enacted a land reform law that allows customary land to be registered. The rationale behind this reform was to address tenure insecurity as well as monitor and track the level and incidence of tenure insecurity and relevant conflicts. According to Lovo [8], Lunduka [9], and Place and Otsuka [10], tenure (in)security in Malawi falls under the customary residence system of a landholder. These customary residence systems determine the rights to use, access, and ownership of land for roughly $69 \%$ of the Malawian population [8]. The objective of this study is to investigate the effect of diverse customary residence systems on contracted tea farmers' agricultural investments in tea and trees (henceforth agroforestry) in Southern Malawi. Furthermore, it is important to analyze which form of customary residence system, among others, increases agricultural productivity.

Malawi has a matrilineal and patrilineal customary residence system based on locational characteristics. The former is widely practiced in the southern part of the country and the latter in the north. In Southern Malawi, where farmers primarily cultivate tea for revenue generation through some form of contract farming, there is a need for them to understand the drivers of investment in their agribusiness to ensure a sustained livelihood and thus alleviate rural poverty. Moreover, population growth is on the increase and is making agricultural land scarce in Southern Malawi, which means it is important to concentrate efforts on increasing productivity [11]. Tea cultivation in Southern Malawi is characterized by the coexistence of large and small farms [11,12], which may influence the productivity of smallholders due to likely spillover effects. Therefore, this study also investigates diverse factors that drive productivity among the smallholder farmers cultivating tea in Southern Malawi.

As mentioned earlier, scholars have produced ambiguous empirical results about the relationship between the customary residence system and investments in land in Malawi. This is mostly because the exact pattern and measurement of tenure security and its effects on agricultural investments under contracted farmers remain unclear. These systems have continuously adapted to contexts from a historical perspective, i.e., appropriation of land during colonization and more recently the fragmentation of land. Whether the customary residence practices affect tenure security and how that relates to investment in land is work in progress that requires a comprehensive approach.

The Food and Agriculture Organization of the United Nations (FAO) [13] argued that as functioning markets develop and as land becomes scarce due to population growth in rural sub-Saharan Africa, land transfers will increase from land-abundant to land-poor households. However, land scarcity will also keep land resources and management within a certain lineage, and they will only be transferred within the community or family members based on customary residence systems in parts of SSA, e.g., Malawi and Burkina Faso [14,15]. This customary residence system may be inefficient and may constrain economic development, in part due to the inability to attract capital investment (e.g., access to credit) [16,17]. Interestingly, limited empirical evidence exists that shows agricultural development (e.g., investments and adoption of innovation) to be constrained by customary residence systems in Africa [18,19]. For example, Austin [20] and Berry [21] found that a growing number of farmers in Ghana and Nigeria, respectively, had invested in cocoa under customary land tenure despite not having a formal land title. Ultimately, customary land tenure systems have been able to avoid imposing unsuitable private land title systems, and these should be considered and investigated from a social, historical, and economic perspective [22,23]. Place and Otsuka [10] and Lunduka [9] argued that agricultural investments are weaker in matrilineal-matrilocal residence systems (i.e., husband moves to the wife's village) compared to patrilineal systems, while other authors in [8] have found no evidence.

The hypothesis in this study is that certain types of customary residence systems of contracted smallholder farmers influence investment in tea and agroforestry. Furthermore, specific customary residence systems, among other factors, may influence the productivity of tea farms in the study area. In 2018, 228 contract farmers were surveyed in the Mulanje District, in the southern region of Malawi. 
The socioeconomic characteristics of the tea farmers and other variables, such as customary residence systems, land tenure, farm characteristics, farmer block, asset, housing facility, transportation, tea expenditure and yield, number of trees, and access to credit, were collected.

The effect of tenure security on investments and productivity was estimated from the cross-sectional data set with linear probability as well as ordinary least squared (OLS) models [24]. The former provides unbiased parameter estimates with minimum variance. The results of this study suggest that for Southern Malawi, matrilocal residence practices influence investment in tea cultivation compared to patrilineal residency. Furthermore, the proximity of smallholder farmers to large commercial tea estates has a positive influence on the farmer's productivity [25].

This study is structured as follows: Section 2 describes the material and methods, including the conceptual framework with a focus on the customary residence systems and investments as well as contract farming in the study areas of Southern Malawi. This section also provides an overview of the methodology. In Section 3, the study results are presented, followed by a discussion of the results and limitations in Section 4. In Section 5, the conclusion of the study is drawn.

\section{Materials and Methods}

There is a need for a broader approach to the adaptation and evolution of the relationship between land tenure security and agricultural investment and productivity due to both the complex nature of the former as well as multiple-actor involvement. Thus, the proposed conceptual framework is a system of concepts and assumptions supported by earlier studies [5]. This study also relies on the work of Arnot et al. [26], Miles et al. [27], Place [5], and Ghebru et al. [28] on tenure security and investment, thereby providing a comprehensive overview. Tenure security exists if farmers expect that the evolution of institutional rules will not decrease the expected utility of their assets. For instance, a landholder is considered tenure secure if their perception of losing their land in the future is low, i.e., nondecreasing expected utility. The expected utility derived from the land by the asset holder is denoted as (Equation (1)):

$$
E\left(U^{R}\right)=f\left(R_{0}, r\left(R_{t}\right), C_{0}, c\left(C_{t}\right)\right)
$$

where $E\left(U^{R}\right)$ is the expected utility derived from land resource $R . R_{0}$ is the status quo of resource benefits, e.g., soil quality, and $r\left(R_{t}\right)$ is its future state of benefits, e.g., level of income. $C_{0}$ is the status quo of institutional rules, e.g., taxes and permits, while $c\left(C_{t}\right)$ is their future state of institutional rule. Both the future states of resource benefits and institutional rules can be denoted respectively as (Equations (2) and (3)):

$$
\begin{aligned}
& r\left(R_{t}\right)=\alpha x_{t}+\varepsilon_{r t} \\
& c\left(C_{t}\right)=\alpha z_{t}+\varepsilon_{c t}
\end{aligned}
$$

where $\alpha x_{t}$ denotes the predicted outcomes of the future state of resource benefits contingent on investment, e.g., in conservation agriculture, while $\alpha z_{t}$ is the predicted future state of institutional rule, e.g., lobbying; $\varepsilon_{r t}$ and $\varepsilon_{c t}$ are respectively the unpredicted components of the future state of resource benefits and institutional rules due to weather, natural catastrophes, war, corrupt practices, etc. For tenure security to prevail in Africa, given the fact that the future state of resource benefits evolves faster over time compared to institutional rules, which are coordinated by social institutions, the emphasis should therefore be on $c\left(C_{t}\right)$. Thus, a landholder assured of the future state of institutional rules has a high level of tenure security independent of the initial property right substance. The expected utility of resources under tenure (in)security can be denoted as (Equations (4) and (5)):

$$
E\left(U^{R} \text { Secure }\right) \rightarrow f \frac{\partial E\left(U^{R}\right)}{\partial c(.)} \geq 0
$$




$$
E\left(U^{R} \text { Insecure }\right) \rightarrow f \frac{\partial E\left(U^{R}\right)}{\partial c(.)}<0
$$

This implies that farmers feels tenure secure if they expect that developments in institutional rules will increase their expected utility. Accordingly, this study adopts this into the conceptual framework by incorporating the development of social norms and rules as a tenure security component. This study presents a comprehensive link between land tenure security and investment incentives based on a certain distinct line of reasoning. First, it is based on the aforementioned argument that future institutional rules change will not adversely affect farmers' expected utility and the benefits derived from investing in the land. Second, it involves the use of land as collateral in order to facilitate access to credit to economically empower landholders. Finally, this type of tenure security can promote the development of land markets, due to transferability. This would incentivize landholders to invest in land, ultimately increasing its market value. The relationship between tenure security and investment has several caveats driven by the individualization of land rights, land commodification, and demographic changes.

In analyzing the relationship between tenure security and investment, it is important to further expand the scope of variables. For instance, other social norms and contract farming are variables that could influence the relationship. Social norms are embedded in customary residence systems, particularly family lineage, and provide different land tenure rights for men and women. However, in parts of SSA, women's land claims are often lower to those of other male members of the family, irrespective of their status [5]. Certain customary residence norms may result in securing land tenure for all. Contract farming for smallholders has the potential to address the failure of functioning output and input markets in rural areas [27]. Access to functioning markets has a higher economic benefit to farmers that have secure tenure [28]. There are different types of contract farming between retailers and farmers, retailers and cooperatives that act on behalf of their members, as well as large estate farms and neighboring smaller farms. In essence, contract farming is established as the so-called nucleus estate schemes, i.e., large agribusinesses and/or farms with high productivity enter into contractual agreements with surrounding smallholders [29]. The farmers deliver products of a specified quantity and quality to buyers at a negotiated price. To increase and improve the supply chain, the buyer often provides extension services such as agricultural practice training as well as production-inputs, loans, logistics, etc. [30]. There are limited studies on the relationship between contract farming and tenure security because contract farming itself does not affect tenure security directly but indirectly through other factors, e.g., investment, productivity. For instance, only farmers confident in their ability to produce food products that meet the quantity and quality requirements will enter into contractual agreements. Grosh [31] found that buyers would rather contract limited smallholders with higher productivity. This could also imply that contracted smallholders may be better off financially and be able to purchase land resulting in a concentration of holdings rather than fragmentation. This would allow for higher investment in agricultural input and productivity on the path of smallholders. Given the higher investment in agricultural input and productivity, due to land tenure security, as well as the corresponding demand, there is economic growth in the agrarian community. Figure 1 illustrates the broader perspective of the aforementioned relationship between tenure, investment, and contract farming.

Malawi is a land-locked country in Eastern Africa that borders Tanzania, Mozambique, and Zambia. Malawi has a total land area of 118,484 square kilometers $\left(\mathrm{km}^{2}\right)$ of which $79.4 \%$ is arable land [32]. Malawi's main economic driver is agriculture and has a population of 17.5 million, which is expected to double by 2038 [33]. More than $80 \%$ of the Malawian population relies on agriculture for income generation, with tobacco, sugar, and tea being the largest contributors to the economy alongside foreign aid [34]. Malawi has one of the highest population growth rates as well as the one of the lowest Human Development Index (HDI) ranks in Africa [35,36]. Thus, the country is experiencing land scarcity as well as poverty, which is due to low productivity in the agriculture sector [33]. In Malawi, government and traditional rule coexist, forming a dual system of governance [37]. Malawi legally 
recognizes three land tenure systems: customary, estate, and public. The customary land tenure system is the predominant system [32]. In Malawi, a variety of customary tenure systems coexist as various ethnic groups have different land rights norms and practices [23]. For instance, in the north of the country, there are the Ngoni and Tumbuka ethnic groups that predominantly practice the patrilineal systems while in the south are the Chewa, Yao, and Lomwe that practice the matrilineal system. Across the ethnic groups of Malawi, smallholders mostly transfer land via inheritance or gifting.

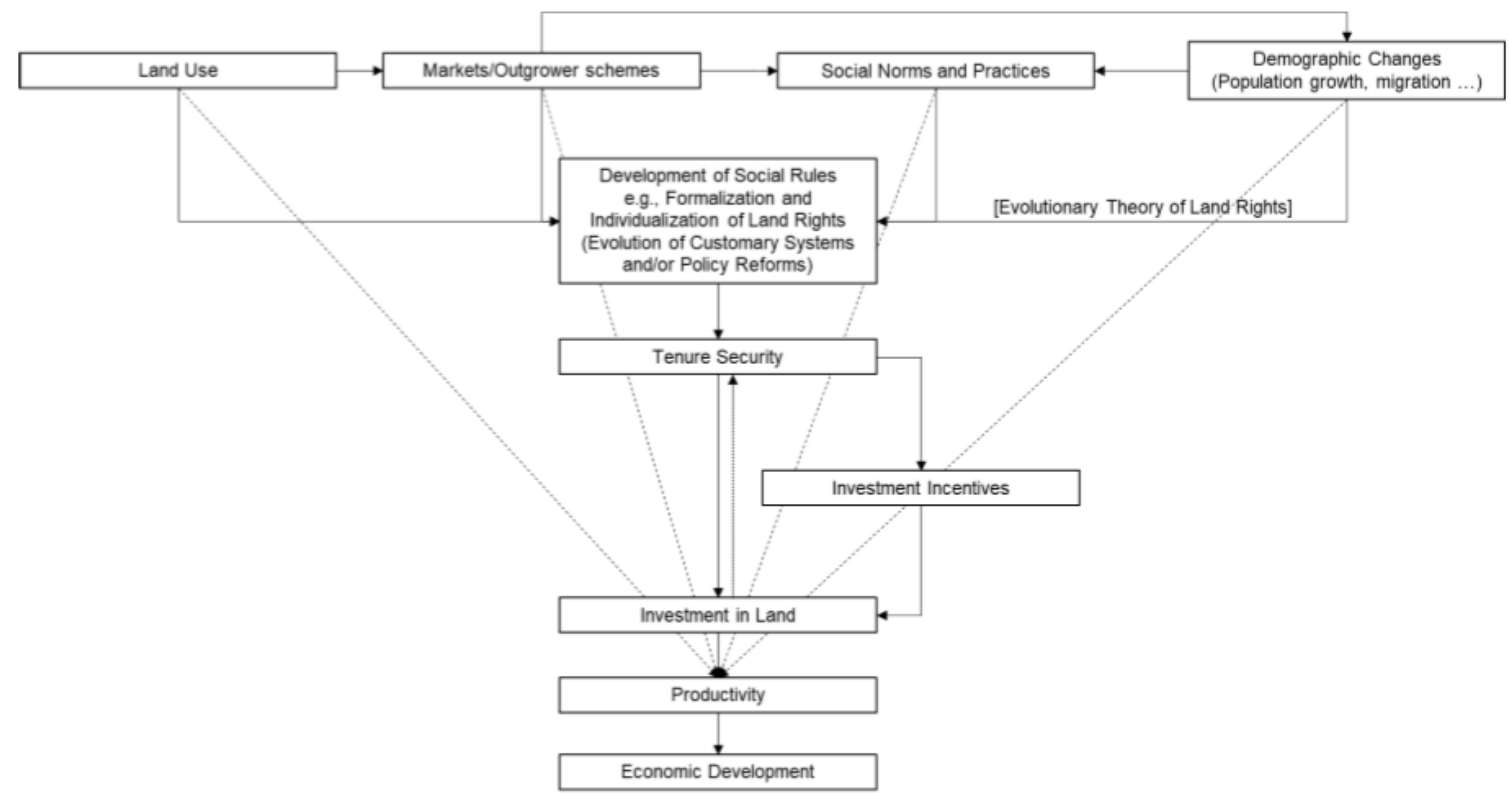

Figure 1. Conceptual framework of tenure security and investments in land in their broader context. Adapted from Feder [29], Place [5] and Ghebru et al. [28].

Land can be inherited along either the male or the female lineage, depending on the regionally dominant system. In the matrilineal systems, which is common in the southern region of Malawi, land is passed along the female line [38]. In the northern region, the patrilineal system is practiced, where land is passed from father to sons [23]. In both matrilineal and patrilineal systems, descendants also receive land as a gift in case of special events such as marriage, birth, or maturity of the heir [14]. The inheritance system is also linked to the residence and marriage, which strongly influences the land rights of the husband or the wife [38]. Couples in Malawi reside either matrilocally, patrilocally, or neolocally after marriage. In matrilocal systems, the husband moves to the wife's location, while in patrilocal systems, the wife moves to the husband's location. Neolocal residence occurs when couples move to a place where they have no family ties. In matrilineal-matrilocal societies, the husband is expected to leave the wife's village and return the land back to her lineage if she dies or they divorce [8]. The man is an outsider in his wife's village, often not respected by his wife's male relatives $[39,40]$. Moreover, the brother of the wife and his descendants have first claim to the resources. Thus, the matrilineal-matrilocal system creates tenure insecurity in that men outside the family lineage can be deprived of the land they cultivate. This may create a situation where married male smallholders living in a matrilineal-matrilocal system are disincentivized from investing in agriculture. Place and Otsuka [10] ranked the Malawian male tenure security according to the customary inheritance and residence system, which is a kind of assurance measurement (see Table 1).

This customary-based tenure security illustrates the complexity of tenure security and its measurement [3]. Furthermore, social norms and practices, markets, land use, and demographic changes have evolved over time, influencing customary inheritance and residence norms. For instance, land reforms across SSA over the years are recognizing customary rule; this would affect the dynamics of customary inheritance and residence norms. 
Table 1. Customary-based tenure security ranking of male land use decision maker.

\begin{tabular}{|c|c|c|}
\hline Inheritance-Residence & Description & Tenure Security \\
\hline Matrilineal-matrilocal & $\begin{array}{l}\text { A husband moves to the wife's village; the land belongs to the } \\
\text { family of the wife. }\end{array}$ & Low \\
\hline Matrilineal-patrilocal & $\begin{array}{l}\text { A wife moves to a husband's village; the land belongs to the } \\
\text { family of the wife }\end{array}$ & \\
\hline Matrilineal-neolocal & $\begin{array}{l}\text { Wife and husband move to a village, not of their origin; the } \\
\text { land belongs to the community of that village. }\end{array}$ & \\
\hline Patrilineal-matrilocal & $\begin{array}{l}\text { A husband moves to a wife's village; the land belongs to the } \\
\text { family of the husband }\end{array}$ & \\
\hline Patrilineal-patrilocal & $\begin{array}{l}\text { A wife moves to a husband's village; the land belongs to the } \\
\text { family of the husband }\end{array}$ & High \\
\hline
\end{tabular}

Source: Place and Otsuka [10].

Tea is one of the major smallholder cash crops cultivated in the southern districts of Malawi. Tea is mostly grown in the Thyolo and Mulanje districts, as the area provides adequate agroclimate conditions [41]. The orange boundaries in Figure 2 represent the agricultural estate boundaries where most of the tea in the study area around Blantyre are produced. According to Chirwa and Kydd [42], after the introduction of tea contract schemes in 1966, contracted smallholders' cultivation areas have grown from 30.8 to 2,900 hectares (ha) of customary land by 2004, producing 810 kilograms per hectare of tealeaf. Even though contracted smallholders produced less than 7\% of all Malawian tea in 2013, the future growth of Malawi's tea sector depends on these farmers [10]. The main tea production comes from the estates because contracted smallholders have low tea bush density on their land (6000-8000 plants/ha) in comparison to estates (15,000 plants/ha) [10]. Tea can provide income for up to 100 years with minimal risk of total crop failure, but it requires a high initial investment in time and money and does not provide direct income in the first few years [10,41]. Another necessary long-term investment that supports tea production is tree planting. To increase the productivity of tea plants, trees are planted to shade the tea plants and plucked tealeaves [42,43]. In the existing literature on tenure security and investment, trees are commonly used as a long-term investment as they can be security- and productivity-enhancing $[23,44,45]$. The investment in trees increases tenure security as well as establishes, to some extent, access and ownership. However, the security-enhancing effect here is trivial given that tenure security in Malawi is based on inheritance and residence norms because they determine access and rights, regardless of the previous investments [46].

This study samples 228 smallholder tea outgrowers in the Mulanje District using a simple random sampling technique of tea associations and cooperatives. These farmers, along with their associations and cooperatives, as well as the cultivation area provide a representative sample for Southern Malawians. The study area is one of the largest tea-growing areas in Malawi with over 5000 smallholder farmers in different farm associations and cooperatives. The particular cooperative under consideration negotiates contract conditions and tealeaf prices for the farmers with the tea processing and growing companies. These companies pay farmers on a monthly basis per kilogram of tealeaf provided and are often owners of tea plantations in the area. A number of tea estates also support the farmers with extension services and tea seedling nurseries. Furthermore, farmers are divided into farmer blocks to increase efficiency. Every farmer block has at least one tealeaf collection point where farmers deliver their produce. At the collection points, tea processing and growing companies weigh, record, and transport tealeaves to the processing facility. Most cooperative farmers grow tea on customary land while processing and growing companies grow tea on freehold land (see Figure 3 for an overview). 


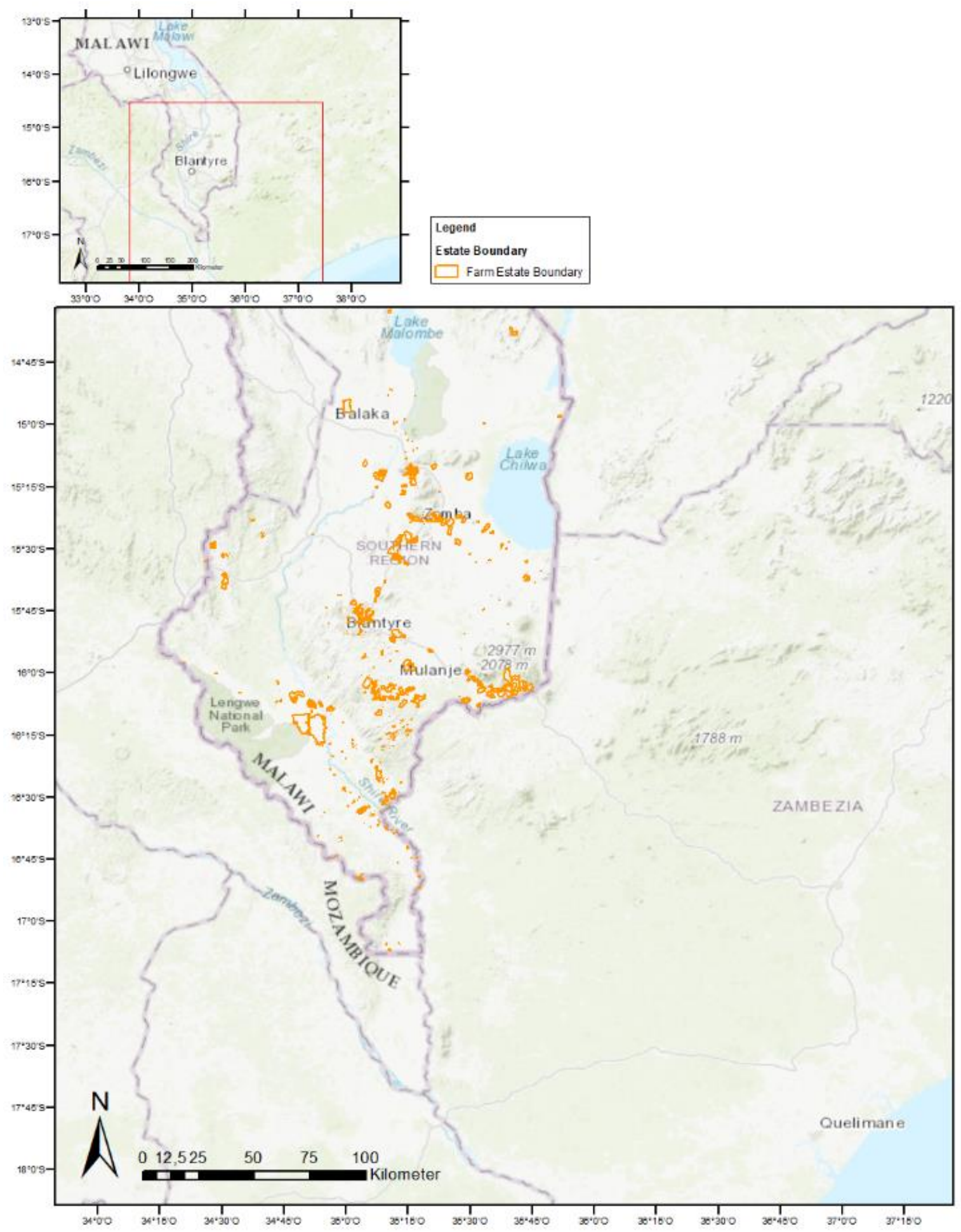

Figure 2. Map of the estate in Southern Malawi. 

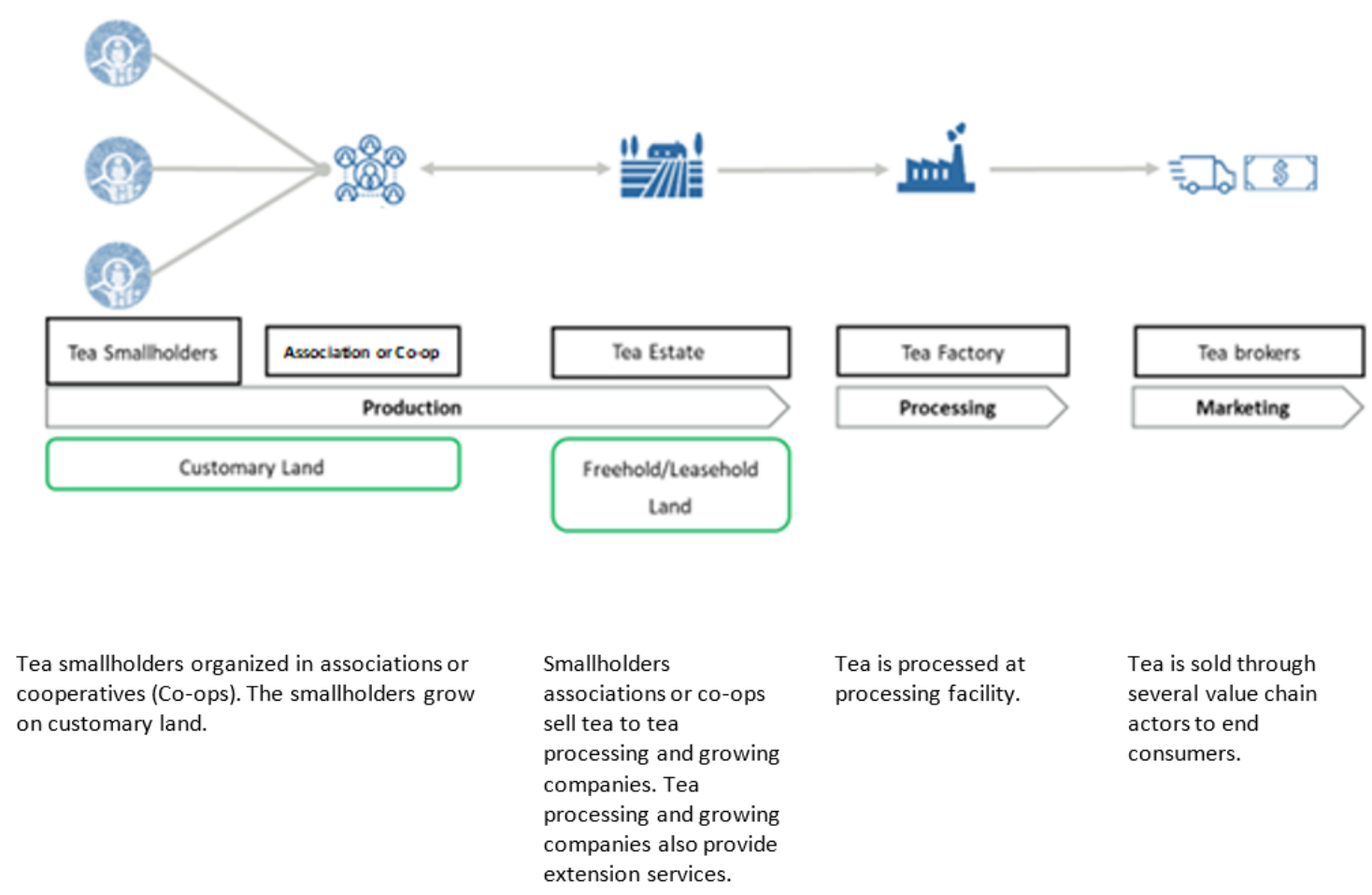

Figure 3. Overview of tea outgrower scheme in Southern Malawi.

Data were collected from four farmer blocks, which represent $16 \%$ of the existing farmer blocks in the study area. The residence types are distributed across the four farmer blocks, A, B, C, and D. Farmer Block A has a fairly diverse mix of all residency systems in the study areas and is somewhat spread further away from commercial estate. The patrilocal residence is prevalent in the northeastern Farmer Block B and has close proximity to commercial estate. The matrilocal residence is mostly practiced in the southern Farmer Blocks $C$ and D, with the former being further away from commercial estate.

This study uses a logit and OLS regression to measure the effect of tenure security on investments in tea plants and agroforestry based on a linear model assumption of the independence of variables, homoscedasticity, and normal distribution [24]. There are two separate functions conducted for the analysis, the investment, and productivity functions. These functions are denoted as (Equations (6) and (7)):

$$
\begin{array}{ll}
Y_{\text {tea or tree }}=\beta_{0}+\beta_{1} X_{1}+\beta_{2} X_{2}+\beta_{3} X_{3} \ldots+\beta_{n} X_{n}+\varepsilon & \rightarrow \text { Logit } \\
Y_{\text {log yield per hectare }}=\beta_{0}+\beta_{1} X_{1}+\beta_{2} X_{2}+\beta_{3} X_{3} \ldots+\beta_{n} X_{n}+\varepsilon & \rightarrow \text { OLS }
\end{array}
$$

where $Y_{\text {tea or tree }}$ is the dependent (discrete) variable that illustrates the investment in tea or trees; $\beta_{0}$ is the intercept, while $\beta_{1}$ to $\beta_{n}$ are the coefficients of interest of each independent variable $X_{1}$ to $X_{n}$; $Y_{\log \text { yield per hectare }}$ is the dependent (continuous) variable that illustrates the (log) yield per hectare of tea, while the other variables are similar to those above with expenditure on tea, i.e., input from the previous year in Table 2 (X6), also expressed in natural log. 
Table 2. Overview of variables used for the regression analysis.

\begin{tabular}{|c|c|c|c|}
\hline Name & Descriptions & Scale & Unit \\
\hline \multicolumn{4}{|l|}{ Dependent Variables } \\
\hline$Y_{\text {tea or tree }}$ (investment in tea or trees) & 1 or 0 ; invested in tree and/or tea in 2017 & Discrete & - \\
\hline$Y_{\text {yield per hectare }}$ (yield per hectare) & Yield per hectare of farmer $i$ on farm $i$ & Continuous & $\mathrm{Kg}$ \\
\hline \multicolumn{4}{|l|}{ Independent Variables } \\
\hline \multicolumn{4}{|l|}{ Tenure security indicator (X1) } \\
\hline Residence & Residence of farmer & Categorical & - \\
\hline Marital status & Single, married, or widowed & Categorical & - \\
\hline \multicolumn{4}{|l|}{ Land tenure $(\mathrm{X} 2)$} \\
\hline Land tenure form & Customary or leasehold & Discrete & - \\
\hline Land acquisition & How farm was acquired (e.g., inheritance) & Categorical & - \\
\hline Land acquisition time & Years of land acquisition & Continuous & - \\
\hline Land dispute & Is there dispute about farm & Discrete & - \\
\hline \multicolumn{4}{|l|}{ Household characteristics (X3) } \\
\hline Household size & Number of adults in household & Continuous & - \\
\hline Asset & Ownership of items (e.g., radio) & Categorical & - \\
\hline Housing structure & Type of housing structure & Discrete & - \\
\hline Transport & Ownership of transport vehicle & Categorical & - \\
\hline Livestock & Ownership of livestock & Categorical & - \\
\hline Other income source & Income source other than tea & Categorical & - \\
\hline Access to finance & Access to loan in the past years & Discrete & - \\
\hline Number of farms & Number of plots owned & Continuous & - \\
\hline \multicolumn{4}{|l|}{ Demographics $(\mathrm{X} 4)$} \\
\hline Gender & Gender of respondent & Discrete & - \\
\hline Age & Age of respondent & Continuous & - \\
\hline Education & Education level of respondent & Categorical & - \\
\hline Literacy & Literacy of respondent & Discrete & - \\
\hline \multicolumn{4}{|l|}{ Farm Characteristics (X5) } \\
\hline Farm size & Measured using geoinformation system & Continuous & ha \\
\hline Land per capita & Farm size per capita of household & Continuous & - \\
\hline Topography & Topography of the farm & Categorical & - \\
\hline \multicolumn{4}{|l|}{ Land Use (X6) } \\
\hline Revenue & Revenue from tea last year & Continuous & USD \\
\hline Expenditure (input) & Expenditure on tea last year & Continuous & USD \\
\hline Age of tea bushes & Year tea bushes was planted & Continuous & Years \\
\hline Tress planted & Number of trees planted & Continuous & - \\
\hline \multicolumn{4}{|l|}{ Farmer block (X7) } \\
\hline Farmer block & Membership of each farmer & Categorical & - \\
\hline
\end{tabular}

USD: United States dollars.

\section{Results}

\subsection{Descriptive Statistics}

The descriptive statistics is presented in Table 3. Overall, 64\% of the smallholders surveyed were married, with half of them stating that they were in either a patrilocal or matrilocal residency. An estimated $96 \%$ of the surveyed smallholder farmers cultivate their farm under either one or the other forms of customary land tenure arrangement. The average household size in the sample is five members. On average, there are two adults in the family between the working age of 14 and 50 years old. The average age of a farmer is 52 years old. On average, a farmer has two farmlands with an average size of 0.2 hectares. The majority (64\%) of the farmlands in this survey are mostly acquired through inheritance. The average age of tea bushes is 28 years, which generated a total of 700 USD in revenue for the farmers under consideration. The average expenditure on the farm by smallholder 
farmers was 92 USD. Only 15\% of the surveyed smallholder reported that they had received a loan in the last years.

Table 3. Descriptive statistics of relevant variables.

\begin{tabular}{|c|c|c|c|c|}
\hline Variable & Mean & SD & Min & $\operatorname{Max}$ \\
\hline \multicolumn{5}{|l|}{ Dependent Variables } \\
\hline Investment in tea or trees, $Y_{\text {tea }}$ or tree & 0.36 & 0.48 & 0 & 1 \\
\hline (Log) Yield per hectare, $Y_{\log \text { yield per hectare }}$ & 9.62 & 0.89 & 7.49 & 12.4 \\
\hline \multicolumn{5}{|l|}{ Independent Variables } \\
\hline \multicolumn{5}{|l|}{ Residence } \\
\hline Patrilocal & 0.26 & 0.44 & 0 & 1 \\
\hline Matrilocal & 0.30 & 0.46 & 0 & 1 \\
\hline Neolocal & 0.01 & 0.09 & 0 & 1 \\
\hline Married purchase & 0.08 & 0.26 & 0 & 1 \\
\hline \multicolumn{5}{|l|}{ Status } \\
\hline Married & 0.63 & 0.48 & 0 & 1 \\
\hline Single & 0.07 & 0.25 & 0 & 1 \\
\hline Separated & 0.07 & 0.26 & 0 & 1 \\
\hline Widowed & 0.22 & 0.41 & 0 & 1 \\
\hline \multicolumn{5}{|l|}{ Land tenure } \\
\hline Land tenure form & 0.96 & 0.18 & 0 & 1 \\
\hline Land acquisition & & & 0 & 1 \\
\hline Gift & 0.19 & 0.4 & 0 & 1 \\
\hline Inheritance & 0.64 & 0.48 & 0 & 1 \\
\hline Chief & 0.03 & 0.20 & 0 & 1 \\
\hline Purchase & 0.08 & 0.29 & 0 & 1 \\
\hline Settlement & 0.02 & 0.15 & 0 & 1 \\
\hline Share-cropping & 0.02 & 0.13 & 0 & 1 \\
\hline Land acquisition time & 28 & 18 & 0 & 105 \\
\hline Land dispute & 0.01 & 0.09 & 0 & 1 \\
\hline \multicolumn{5}{|l|}{ Household characteristics } \\
\hline Household size & 5 & 2 & 1 & 12 \\
\hline Adults & 2 & 1 & 0 & 9 \\
\hline \multicolumn{5}{|l|}{ Asset } \\
\hline Phone & 0.19 & 0.39 & 0 & 1 \\
\hline Phone and radio & 0.46 & 0.50 & 0 & 1 \\
\hline TV & 0.02 & 0.14 & 0 & 1 \\
\hline Fridge & 0.04 & 0.19 & 0 & 1 \\
\hline Housing structure & 0.54 & 0.50 & 0 & 1 \\
\hline \multicolumn{5}{|l|}{ Transport } \\
\hline None & 0.22 & 0.41 & 0 & 1 \\
\hline Bicycle & 0.59 & 0.49 & 0 & 1 \\
\hline Motorcycle & 0.17 & 0.38 & 0 & 1 \\
\hline Car & 0.02 & 0.13 & 0 & 1 \\
\hline \multicolumn{5}{|l|}{ Livestock } \\
\hline None & 0.35 & 0.48 & 0 & 1 \\
\hline Chicken & 0.44 & 0.50 & 0 & 1 \\
\hline Pigs & 0.07 & 0.26 & 0 & 1 \\
\hline Others & 0.14 & 0.35 & 0 & 1 \\
\hline \multicolumn{5}{|l|}{ Other income source } \\
\hline None & 0.25 & 0.44 & 0 & 1 \\
\hline Farming & 0.32 & 0.47 & 0 & 1 \\
\hline Labor & 0.29 & 0.46 & 0 & 1 \\
\hline Employed & 0.07 & 0.26 & 0 & 1 \\
\hline Access to finance & 0.15 & 0.36 & 0 & 1 \\
\hline Numbers of farm & 2 & 1 & 1 & 5 \\
\hline
\end{tabular}


Table 3. Cont

\begin{tabular}{ccccc}
\hline Variable & Mean & SD & Min & Max \\
\hline Demographics & & & & \\
Gender & 0.60 & 0.49 & 0 & 1 \\
Age & 53 & 16 & 22 & 103 \\
Education & & & & \\
None & 0.29 & 0.45 & 0 & 1 \\
Primary & 0.54 & 0.50 & 0 & 1 \\
Secondary & 0.15 & 0.36 & 0 & 1 \\
Tertiary & 0.02 & 0.15 & 0 & 1 \\
Literacy & 0.30 & 0.46 & & \\
Farm characteristics & & & & \\
Farm size & 0.20 & 015 & 0 & 1 \\
Topography & & & & \\
Flat & 0.22 & 0.42 & 0 & 1 \\
Light slope & 0.40 & 0.49 & 0 & 1 \\
Steep slope & 0.38 & 0.49 & 0 & 1 \\
\hline Land use & & & & \\
Revenue & 700 & 1343 & 85 & 12,366 \\
Tea expenditure (input) & 92 & 89 & 0 & 651 \\
Age of tea bushes & 28 & 12 & 0 & 67 \\
Tress planted & 12 & 20 & 1 & 121 \\
\hline Farmer block & & & & \\
A & 0.23 & 0.42 & 0 & 1 \\
B & 0.25 & 0.44 & 0 & 1 \\
C & 0.27 & 0.44 & 0 & 1 \\
D & 0.26 & 0.44 & 0 & 1 \\
\hline
\end{tabular}

\subsection{Regression Results}

The results of the regression analysis of Equations (6) and (7) are presented in Tables 4 and 5. Model 1 illustrates the basis model of the analysis, extended by the other listed (relevant) independent variables in subsequent models. The difference in the number of observations between Tables 4 and 5 is due to missing observations for certain independent variables in the respective estimations. In Table 4 we present the marginal effect of the logit regression that is statistically significant, as this can be adequately interpreted. The results suggest that matrilocal residence is ca. $20 \%$ more likely to invest in tea or trees compared to patrilocal residency. Conversely, widows are ca. $20 \%$ less likely to invest in tea or trees compared to patrilocal residency. Smallholder farmers that acquire land through inheritance were ca. $16 \%$ less likely to invest in tea or trees compared to those that receive land as a gift. A female smallholder was $20 \%$ less likely to invest in tea or trees compared to their male counterpart. Those with primary education were $15 \%$ less likely to invest in tea or trees compared to those without formal education.

The productivity analysis is presented in Table 5. Contrary to the investment analysis above, nonstatistically significant variables were also reported. The results suggest that increase in tea inputs, such as fertilizer, pesticide, results in increases in tea bushes output. Those that inherited land were less productive compared to those that receive farmland as a gift from other sources, e.g., the government. Neolocal farmers were less productive compared to the patrilocal customary system (weak statistical significance). The larger the household size, the more productive the tea-growing smallholder (weak statistical significance). Conversely, the higher the number of working age adults in the household, the less productive the tea outgrowing smallholder. The results also suggest that increasing the farm size of tea-growing smallholders does not necessarily lead to higher productivity. Furthermore, the higher the number of trees on the farms (agroforestry), the lower the productivity. Farmers in Blocks B and $\mathrm{D}$ were found to be more productive than farmers in Block A. 
Table 4. Significant marginal effects of variables on investment in tea or trees (Logit Equation (6)).

\begin{tabular}{|c|c|c|c|}
\hline Investment in Tea or Trees $Y_{\text {tea }}$ or tree & Model 1 & Model 2 & Model 3 \\
\hline Matrilocal & $\begin{array}{l}0.18^{*} \\
(1.66)\end{array}$ & $\begin{array}{l}0.20 * \\
(1.86)\end{array}$ & $\begin{array}{l}0.22 * * \\
(2.10)\end{array}$ \\
\hline Widowed & $\begin{array}{c}-0.23^{* *} \\
(-2.03)\end{array}$ & $\begin{array}{l}-0.21 * \\
(-1.89)\end{array}$ & $\begin{array}{l}-0.18^{*} \\
(-1.63)\end{array}$ \\
\hline Inheritance & $\begin{array}{l}-0.18^{*} \\
(-1.89)\end{array}$ & $\begin{array}{l}-0.16^{*} \\
(-1.77)\end{array}$ & $\begin{array}{l}-0.16^{*} \\
(-1.83)\end{array}$ \\
\hline Gender & $\begin{array}{c}-0.23^{* * *} \\
(-2.75)\end{array}$ & $\begin{array}{c}-0.20 * * * \\
(-2.45)\end{array}$ & $\begin{array}{c}-0.21^{* * * *} \\
(-2.45)\end{array}$ \\
\hline Number of farms & & $\begin{array}{c}0.11^{* * * *} \\
(3.16)\end{array}$ & $\begin{array}{l}0.07 * \\
(1.75)\end{array}$ \\
\hline Education (primary) & & & $\begin{array}{l}-0.15^{*} \\
(-1.69)\end{array}$ \\
\hline Tea labor expenditure & & & $\begin{array}{c}0.001 \text { * } \\
(1.88)\end{array}$ \\
\hline Observations & 135 & 135 & 135 \\
\hline
\end{tabular}

Table 5. Effects of specific variables on yield per hectare (OLS Equation (7)).

\begin{tabular}{|c|c|c|c|}
\hline 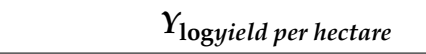 & Model 1 & Model 2 & Model 3 \\
\hline Log Tea Expenditure (Inputs) & $\begin{array}{l}0.150 * * \\
(0.0725)\end{array}$ & $\begin{array}{l}0.157^{* *} \\
(0.0789)\end{array}$ & $\begin{array}{l}-0.0302 \\
(0.0675)\end{array}$ \\
\hline Inheritance & $\begin{array}{c}-0.451 * * * \\
(0.167)\end{array}$ & $\begin{array}{c}-0.419^{* *} \\
(0.167)\end{array}$ & $\begin{array}{l}-0.222 \\
(0.148)\end{array}$ \\
\hline Matrilocal & & $\begin{array}{c}0.125 \\
(0.164)\end{array}$ & $\begin{array}{c}0.209 \\
(0.142)\end{array}$ \\
\hline Neolocal & & $\begin{array}{l}-0.717 \\
(0.514)\end{array}$ & $\begin{array}{c}-1.301 \text { ** } \\
0.209\end{array}$ \\
\hline Household Size & & $\begin{array}{l}0.0721 \text { ** } \\
(0.0341)\end{array}$ & $\begin{array}{c}0.0661^{* *} \\
(0.0317)\end{array}$ \\
\hline Adult & & $\begin{array}{c}-0.165^{* * *} \\
(0.0531)\end{array}$ & $\begin{array}{c}-0.171^{* * *} \\
(0.0505)\end{array}$ \\
\hline Farms Size & & & $\begin{array}{c}-3.27^{* * * *} \\
(0.32)\end{array}$ \\
\hline Number of trees & & & $\begin{array}{c}-0.01 * * \\
(0.004)\end{array}$ \\
\hline Farmer Block B & & & $\begin{array}{c}1.083^{* * *} \\
(0.180)\end{array}$ \\
\hline Farmer Block D & & & $\begin{array}{c}0.392^{* * *} \\
(0.139)\end{array}$ \\
\hline Constant & $\begin{array}{c}8.366^{* * *} \\
(0.776)\end{array}$ & $\begin{array}{c}8.171^{* * *} \\
(0.806)\end{array}$ & $\begin{array}{c}9.647 * * * \\
(0.677)\end{array}$ \\
\hline Observations & 224 & 224 & 224 \\
\hline R-squared & 0.071 & 0.124 & 0.365 \\
\hline
\end{tabular}

Given that certain econometric issues can arise due to omitted variables, the relationship between dependent and independent variable as well as the error term (endogenity) in an OLS regression interpretation of results should be done with caution. This study, however, undertakes some basic tests. The Durbin Watson Test of an OLS regression of 1.83 implies that there is no autocorrelation, i.e., serial correlation between the error terms such that our significant results may be valid. Furthermore, the white test result of 127.98 and a p-value of 0.19 imply there is no major issue with the heteroscedasticity of the error term (robust option). While the use of a two-stage least square estimation (2SLS) would 
ensure that endogenity is adequately addressed, finding a suitable instrumental variable (IV) in the sample is unlikely.

\section{Discussion}

This study investigates whether the customary residence of (married) farmers influences agricultural investment in tea and agroforestry under contract farming conditions. Furthermore, it explores which factors, including customary residence systems, influence the productivity of contracted tea farms in Southern Malawi. The results of this study contribute to the literature on the relationship between tenure security, agricultural investment, and productivity among contracted smallholders in Malawi [7,44,46]. While Place and Otsuka [10] and Lunduka [9] found that the probability of investing in agroforestry is higher among patrilocal and neolocal residence households compared to matrilocal residence households, this study found the opposite with regards to investment in tea and/or agroforestry. This could be because the study area of Southern Malawi is dominated by the matrilineal-matrilocal customary system. Matchaya [47] found that female-headed households in matrilineal societies are more land secure than males, which could also incentivize investment in land for its long-term benefit. Lovo [8] found that (male) decision-makers in matrilineal-matrilocal villages were more likely to invest in trees, as this consolidates their tenure security. This study found that widows were less likely to invest in tea or agroforestry. While widows in parts of sub-Saharan Africa (e.g., Zambia) have been found to undertake limited investment in agricultural land that they are unable to inherit, the result for Southern Malawi is somewhat surprising, given the prevalence of the matrilineal-matrilocal system [48]. This could be an indication that women are also disadvantaged under the matrilineal-matrilocal system. Inheritance of land, compared to other forms of land acquisition such as a gift from the village chief, does not seem to drive investment in tea or agroforestry by smallholders in Southern Malawi. Gibson and Gurmu [48] found that land inheritance compared to other forms of land allocation in parts of sub-Saharan Africa (e.g., Ethiopia) was inefficient due to diminishing resources and competition from a large number of siblings. Place and Otsuka [10] attributed fragmentation of land in matrilineal-matrilocal systems in Southern Malawi to a large number of competing heirs. This may likely dissuade investment in tea or agroforestry. The results of this study also suggest that there is gender disparity in investment in tea or agroforestry with women at a disadvantage. Meijer et al. [49] argued that agroforestry and management is a male-dominated sector in Malawi. Chirwa [50] also found a negative relationship between fertilizer investment and/or adoption and the female-headed smallholder agrarian households in Southern Malawi. Smallholders having more than one farm in Malawi were more likely to invest in tea or agroforestry, a finding that is also similar to that of other studies (see [44,51]). Chirwa [50] also found that investment and/or adoption in fertilizer and improved seeds in Malawi was driven by land holdings. This study found that farmers with primary-level education were less likely to undertake agricultural investment in tea and agroforestry in Malawi. This is similar to the findings of Deininger and Jin [52] and Chirwa [53] that well-educated smallholder farmers in Malawi were likely to invest in agricultural technologies compare to less educated smallholders.

This study establishes a basis for the production function by estimating the relationship between inputs (e.g., fertilizer, pesticide) and the output (i.e., yield per hectare). The positive and statistically significant relationship shows that the model predictions are plausible. Lunduka [9] and Place and Otsuka [10] argued that investments in agricultural inputs such as (in)organic fertilizer, hired labor, hybrid seeds, and pesticide in Malawi result in increases in agricultural production efficiency. The results of this study suggest that smallholders in neolocal residence systems were less productive compared to those in the patrilocal system with weak statistical significance. Lunduka [9] found that those households that were tenure insecure in Malawi had lower production efficiency compared to tenure secure households. Considering that the predominant customary residence in Southern Malawi is matrilineal-matrilocal, farms under this system could be expected to have lower productivity relative to others. However, Place and Otsuka [10] found that for maize and tobacco cultivation in Malawi, 
the diverse tenure systems did not influence productivity. This study found that household size has a positive correlation with tea yield per hectare and may signify more reliance on household labor. This is similar to the results of the study by Chirwa and Kydd [54] for tea outgrowing smallholders in Malawi. This study also found that as the number of working age adults in the household increases, tea yield per hectare declines, which is evidence for the diminishing return to labor. While Benjamin et al. [55] found that a large farm size could lead to favorable financial credit conditions for smallholder farmers in parts of sub-Saharan Africa, this study found that increasing farm size among tea-growing smallholders in Malawi does not result in high productivity. The results also suggest that smallholder farms in Farmer Blocks B and D were more productive compared to those in Farmer Block A. While there is limited information on the differences in the mode of operation between the farmer blocks, a possible explanation is the proximity to estates and a likely spillover effect of agronomic practices. Chirwa [53] and Chirwa and Kydd [54] argued that contractual arrangements between smallholder farmers and commercial estates result in higher productivity for the farmers compared to those that trade with grower-leased factories and state-owned enterprises. Another important outcome of this result is that farmers in the predominately-matrilocal residence system Block D, with close proximity to commercial estates, are more productive, confirming the initial findings of the positive but insignificant relationship between matrilocal residency and productivity. This also implies that farmers in blocks with a predominantly patrilocal residence system can be productive if they are in close proximity to commercial estates.

Some of the variables of the models can be ascertain as ecosystem services (agroforestry) and marketed outputs (yield). According to Benjamin and Sauer [56], the relationship between these variables can be competitive, complementary, or supplementary in nature. The relationship between these variables in parts of sub-Saharan Africa (e.g., Kenya) was found to be more complementary and supplementary rather competitive [56]. Therefore, it is important to investigate such relationships in a Malawian context. In the study area, as the number of trees on farmland increases, the yield per hectare of tea decreases, which may imply a competitive relationship between the crop and ecosystem services once it passes a certain threshold [56]. It is important to mention at this stage that there is a possible existence of selection bias and endogenity in this analysis. Some of the farmers may self-select into specific blocks based on particular attributes such as education, farm size, etc. Thus, future analysis should use certain methods such as propensity score matching (PSM) and/or Heckman selection as well as a two-stage model to address some of these issues.

\section{Conclusions}

The customary land tenure systems discourse in sub-Saharan Africa is relevant for achieving sustainable agricultural development. Findings from the discourse affect food security and the livelihoods of millions of smallholder farmers. Customary tenure systems across SSA differ and have evolved over time. Their impact on existing farming models, such as contract farming, should also be taken into consideration. Therefore, it is important to conduct country-, region-, and case-specific analyses. This study analyzes the determinants of investment in tea and agroforestry and the factors that influence tea productivity for diverse customary residences under contract farming in Southern Malawi. The results seem to suggest that the predominant matrilocal tenure system in the study area positively influences investment in tea and agroforestry. Other factors such as the proximity of small farms to commercial estates as well as household size also have a similar effect on productivity. This is evidence for the so-called spillover effect where farms close to profitable large-scale commercial estates imitate their operations. Gender bias in agricultural investment is prevalent among the tea outgrowers in Southern Malawi while the trait of having a higher level of education continues to drive investment among smallholders.

There is a need for policy to address gender gaps in Southern Malawi despite the dominance of a matrilineal-matrilocal system, as women may be vulnerable and insecure even in this customary system. Furthermore, emphasis should also be placed on providing less educated tea outgrowing 
smallholder farmers with the right tools that induces investment in agriculture as a way of safeguarding their livelihood. Thus, the use of extension services and farm management intermediaries could contribute to higher productivity in agricultural (tea) production [54-56]. There is a need to conduct a detailed gender sensitive analysis on how future land reforms that are related to customary systems and contract farming would impact agricultural investment and productivity beyond just the agricultural input in Malawi.

Funding: This research was funded by Jonathan Seipl.

Acknowledgments: Special thanks are given to Jonathan Seipl for the concept and data collection and also Stefania Lovo for taking time to introduce her work and ideas. We would also like to thank Tobias Bendzko from the Technical University of Munich, Germany for supporting the GIS-related work.

Conflicts of Interest: The authors declare no conflict of interest.

\section{References}

1. Lowder, S.K.; Skoet, J.; Raney, T. The number, size, and distribution of farms, smallholder farms, and family farms worldwide. World Dev. 2016, 87, 16-29. [CrossRef]

2. Bromley, D.W. Environment and Economy: Property Rights and Public Policy; Basil Blackwell Ltd.: Oxford, UK, 1991.

3. Arnot, C.D.; Luckert, M.K.; Boxall, P.C. What Is Tenure Security? Conceptual Implications for Empirical Analysis. Land Econ. 2011, 87, 297-311. [CrossRef]

4. Lawry, S.; Samii, C.; Hall, R.; Leopold, A.; Hornby, D.; Mtero, F. The impact of land property rights interventions on investment and agricultural productivity in developing countries: A systematic review. J. Dev. Eff. 2016, 9, 61-81. [CrossRef]

5. Place, F. Land Tenure and Agricultural Productivity in Africa: A Comparative Analysis of the Economics Literature and Recent Policy Strategies and Reforms. World Dev. 2009, 37, 1326-1336. [CrossRef]

6. Fenske, J. Land tenure and investment incentives: Evidence from West Africa. J. Dev. Econ. 2011, 95, 137-156. [CrossRef]

7. Deininger, K.; Xia, F.; Holden, S. Gendered Incidence and Impacts of Tenure Insecurity on Agricultural Performance in Malawi's Customary Tenure System. J. Dev. Stud. 2019, 55, 597-619. [CrossRef]

8. Lovo, S. Tenure insecurity and investment in soil conservation. Evidence from Malawi. World Dev. 2006, 78, 219-229. [CrossRef]

9. Lunduka, R. Land Rental Markets, Investment and Productivity Under Customary Land Tenure Systems in Malawi; Norwegian University of Life Sciences: As, Norway, 2009.

10. Place, F.; Otsuka, K. Tenure, agricultural investment, and productivity in the customary tenure sector of Malawi. Econ. Dev. Cult. Chang. 2001, 50,77-99. [CrossRef]

11. Nankumba, J.S.; Kalua, B.; Kishindo, P. Contract Farming and Outgrower Schemes in Malawi: The Case Study of Tea and Sugar Smallholder Authorities: Research Report; Centre for Social Research, University of Malawi: Zomba, Malawi, 1989.

12. Chinigò, D. Rural radicalism and the historical land conflict in the Malawian tea economy. J. S. Afr. Stud. 2016, 42, 283-297. [CrossRef]

13. FAO. Analysis of Price Incentives for Tea in Malawi; Technical notes series; MAFAP; FAO: Rome, Italy, 2015.

14. Kishindo, P.; Mvula, P. Malawi's land problem and potential for rural conflict. J. Contemp. Afr. Stud. 2017, 35, 370-382. [CrossRef]

15. Holden, S.T.; Otsuka, K. The roles of land tenure reforms and land markets in the context of population growth and land use intensification in Africa. Food Policy 2014, 48, 88-97. [CrossRef]

16. Matlon, P. Indigenous land use systems and investments in soil fertility in Burkina Faso. In Searching for Land Tenure Security in Africa; The World Bank: Washington, DC, USA, 1994; pp. 41-69.

17. Takane, T. Customary land tenure, inheritance rules, and smallholder farmers in Malawi. J. S. Afr. Stud. 2008, 34, 269-291. [CrossRef]

18. Johnson, O.E.G. Economic analysis, the legal framework and land tenure systems. J. Law Econ. 1972, 15, 259-276. 
19. Feder, G.; Feeny, D. Land tenure and property rights: Theory and implications for development policy. World Bank Econ. Rev. 1991, 5, 135-153. [CrossRef]

20. Noronha, R. A Review of the Literature on Land Tenure Systems in Sub-Saharan Africa; Agriculture and Rural Development Department, World Bank: Washington, DC, USA, 1985.

21. Austin, G. Labour, Land, and Capital in Ghana: From Slavery to Free Labour in Asante, 1807-1956; Boydell \& Brewer: Suffolk, UK; Woodbridge, UK, 2005; Volume 18.

22. Berry, S.S. Cocoa, Custom, and Socio-Economic Change in Rural Western Nigeria; Clarendon Press: Oxford, UK, 1975.

23. Riddell, J.C.; Dickerman, C. Country Profiles of Land Tenure: Africa 1986; Land Tenure Center, University of Wisconsin-Madison: Madison, WI, USA, 1986.

24. Bruce, J.W.; Migot-Adholia, S.E. Searching for Land Tenure Security in Africa; Kendall/Hunt Publishing Company: Dubuque, IA, USA, 1994.

25. Deininger, K. Land Policies for Growth and Poverty Reduction; World Bank Publications: Washington, DC, USA, 2003.

26. Alchian, A.A.; Demsetz, H. The property right paradigm. J. Econ. Hist. 1973, 33, 16-27. [CrossRef]

27. Miles, M.B.; Huberman, A.M.; Huberman, M.A.; Huberman, M. Qualitative data analysis. In An Expanded Sourcebook; Sage: Newcastle upon Tyne, UK, 1994.

28. Ghebru, H.; Khan, H.; Lambrecht, I. Perceived Land Tenure Security and Rural Transformation: Empirical Evidence from Ghana; IFPRI Discussion Paper 1545; International Food Policy Research Institute (IFPRI): Washington, DC, USA, 2006.

29. Feder, G. The implications of land registration and titling in Thailand. In Proceedings of the International Association for Applied Econometrics, Buenos Aires, Argentina, 24-31 August 1988; pp. 771-781.

30. Wooldridge, J.M. Introductory Econometrics: A Modern Approach; Nelson Education: Toronto, ON, Canada, 2015.

31. Grosh, B. Contract farming in Africa: An application of the new institutional economics. J. Afr. Econ. 1994, 3, 231-261. [CrossRef]

32. Bruce, J.W. Simple solutions to complex problems: Land formalization as a 'silver bullet'. In Fair Land Governance: How to Legalise Land Rights for Rural Development; Leiden University Press: Leiden, Holland, 2012; pp. 31-55.

33. Baumann, P. Equity and Efficiency in Contract Farming Schemes: The Experience of Agricultural Tree Crops; Overseas Development Institute: London, UK, 2000; Volume 111.

34. Eaton, C.; Shepherd, A. Contract Farming: Partnerships for Growth; Food \& Agriculture Organization: Rome, Italy, 2001.

35. Key, N.; Runsten, D. Contract farming, smallholders, and rural development in Latin America: The organization of agroprocessing firms and the scale of outgrower production. World Dev. 1999, 27, 381-401. [CrossRef]

36. Kishindo, P. Customary land tenure and the new land policy in Malawi. J. Contemp. Afr. Stud. 2004, 22, 213-225. [CrossRef]

37. World Bank. The World Bank in Malawi. 2020. Available online: https://www.worldbank.org/en/country/ malawi/overview (accessed on 15 May 2020).

38. Peters, P.E.; Kambewa, D. Whose security? Deepening social conflict over 'customary'land in the shadow of land tenure reform in Malawi. J. Mod. Afr. Stud. 2007, 45, 447-472. [CrossRef]

39. World Bank. Population Density (People per sq. km of Land Area). 2007. Available online: https: //data.worldbank.org/indicator/EN.POP.DNST (accessed on 15 May 2020).

40. UNDP. Human Development Index and its Components. 2020. Available online: http://hdr.undp.org/en/data (accessed on 15 May 2020).

41. Eggen, Ø. Chiefs and everyday governance: Parallel state organisations in Malawi. J. S. Afr. Stud. 2011, 37, 313-331. [CrossRef]

42. Chirwa, E.; Kydd, J. Study on Farmer Organisations in Smallholder Tea in Malawi. 2005. Available online: https://agris.fao.org/agris-search/search.do?recordID=GB2012102311 (accessed on 15 May 2020).

43. Peters, P.E. “Our daughters inherit our land, but our sons use their wives' fields": Matrilineal-matrilocal land tenure and the New Land Policy in Malawi. J. East. Afr. Stud. 2010, 4, 179-199. [CrossRef] 
44. Miller, D. Matriliny and social change; how are women of rural Malawi managing. In Proceedings of the CASID, Montreal, QC, Canada, 2 June 1996.

45. Kishindo, P. Emerging Reality in Customary Land Tenure: The Case of Kachenga Village in Balaka District, Southern Malawi. Afr. Sociol. Rev. Rev. Afr. De Sociol. 2010, 14, 102-111. [CrossRef]

46. Carr, M.K.V. Advances in Tea Agronomy; Cambridge University Press: Cambridge, UK, 2018.

47. Matchaya, G. Land ownership security in Malawi. Afr. J. Agric. Res. 2009, 4, 1-13.

48. Gibson, M.A.; Gurmu, E. Land inheritance establishes sibling competition for marriage and reproduction in rural Ethiopia. Proc. Natl. Acad. Sci. USA 2011, 108, 2200-2204. [CrossRef] [PubMed]

49. Meijer, S.S.; Sileshi, G.W.; Kundhlande, G.; Catacutan, D.; Nieuwenhuis, M. The role of gender and kinship structure in household decision-making for agriculture and tree planting in Malawi. J. Gend. Agric. Food Secur. (Agri-Gender) 2015, 1, 54-76.

50. Chirwa, E.W. Adoption of fertilizer and hybrid seeds by smallholder maize farmers in Southern Malawi. Dev. S. Afr. 2005, 22, 1-12. [CrossRef]

51. Pound, B. Branching Out: Fairtrade in Malawi: Monitoring the Impact of Fairtrade on Five Certified Organizations; Fairtrade Africa and the Fairtrade Foundation: London, UK, 2013.

52. Deininger, K.; Jin, S. 'The impact of property rights on households' investment, risk coping, and policy preferences: Evidence from China'. Econ. Dev. Cult. Chang. 2003, 53, 551-882. [CrossRef]

53. Chirwa, E. Land tenure, farm investments and food production in Malawi. In Institutions and Pro-Poor Growth (IPPG) Research Programme; Discussion Paper; University of Manchester: Manchester, UK, 2008; Volume 18.

54. Chirwa, E.W.; Kydd, J. Farm-Level Productivity in Smallholder tea Farming in Malawi: Do Contractual Arrangements Matter? Working Paper; University of Malawi, Chancellor College, Department of Economics: Zomba, Malawi, 2006; Volume 3.

55. Benjamin, E.O.; Blum, M.; Punt, M. The impact of extension and ecosystem services on smallholder's credit constraint. J. Dev. Areas 2016, 50, 333-350. [CrossRef]

56. Benjamin, E.O.; Sauer, J. The cost effectiveness of payments for ecosystem services—Smallholders and agroforestry in Africa. Land Use Policy 2018, 71, 293-302. [CrossRef]

(C) 2020 by the author. Licensee MDPI, Basel, Switzerland. This article is an open access article distributed under the terms and conditions of the Creative Commons Attribution (CC BY) license (http://creativecommons.org/licenses/by/4.0/). 